\title{
Neo Sufisme: Sebuah Gerakan Pembaharuan Moral
}

\author{
M. Anwar Firdausi
}

Penulis adalah Dosen Universitas /slam Negeri (UIN) Malang

\begin{abstract}
Really Neo Sufism is not e new term in the Islamic studies because this term is as the continuation of the Islamic studies itself (Sufism) that is always based on the Qor'an and Hadits. One of Neo Sufism movements that took place in North Africa is as a mode of the Islamic studies movement that tries to think over the Sufism thought in syariat environment that that is very active in under going moral revival that often appears in politic activities.
\end{abstract}

Tulisan ini mencoba menguraikan gerakan neo-sufisme yang dianggap sebagai sebuah model gerakan pemikiran keislaman yang berupaya untuk mencoba meletakkan ajaran-ajaran tasawuf ke dalam wacana syari'ah. Terutama yang terjadi pada gerakan Sanusiyah ,di Afrika Utara pada abad 18 dan 19. Dan gerakannya adalah aktivis dengan program yang bersifat murni pembaharuan moral yang muncul dalam tindakan politik. Gerakan ini muncul sebagai salah satu jawaban atau respon terhadap kondisi dunia Islam yang dalam keadaan krisis sosial, budaya, politik, pemikiran serta keagamaan.

Sebenarnya istilah neo-sufisme yang dimunculkan Fazlur Rahman ini, tentunya menimbulkan diskusi yang panjang. Menurutnya neo-sufisme adalah 
sufisme yang telah diperbaharui (reformed sufism). Sebagian besar sifat eskatikmetafisis dan kandungan mystiko-filosofis yang sebelumnya dominan dalam sufisme kini digantikan kandungannya dengan postulat-postulat agama (Islam) ortodoks. ' Begitu juga menurut Azyumardi azra, sufisme abad pertengahan yang berbau panteisme dan menolak dunia, digantikan sufisme dengan organisasi dan struktur yang penuh aktivis, yang mengembangkan sikap lebih positif terhadap dunia, baik didalam kerangka politik, moral maupun spiritual. ${ }^{2}$

Dan gerakan-gerakan neo-sufisme pada umumnya berusaha untuk meletakkan ajaran-ajaran sufisme ke dalam pangkuan ortodoksi lalu mengaktualisasikannya. Sebagaimana yang dilakukan oleh gerakan yang dipelopori Syah Waliullah di India, gerakan Idrisiyah, Sanusiyah di Afrika.

Gerakan Sanusiyah yang merupakan wakil par exellence dari gerakan neo-sufisme yang sama sekali aktivis dalam pembaharuan moral yang bersentuhan dengan kegiatan politik.

\section{Para Pemimpin Gerakan Sanusiyah}

Gerakan ini didirikan oleh Muhammad Bin Ali al Sanusi yang lahir pada tanggal 22 Desember 1787 di Wasithah Al Jazair. Ia tertarik dengan sufisme ketika berada di Maroko dengan banyak mengunjungi zawiyah-zawiyah yang ada pada masa itu. Dari maroko ia lanjutkan studinya ke Makkah, dan disana bertemu dengan Ahmad Bin Idris, pendiri gerakan Idrisiyah yang membuatnya semakin tertarik dengan sufisme yang pada masa - masa berikutnya melahirkan gerakan sanusiyah.

Selanjutnya kehidupannya tak pernah terpisahkan dari sufisme yang diajari oleh Ahmad bin Idris hingga di Hijaz ia memproklamasikan berdirinya gerakan Sanusiyah. Sejak itu gerakan Sanusiyah berkembang cepat, sampai-sampai ia terusir dari Makkah pada tahun 1840 karena para ulama dan penguasa Turki Utsmani menggangap berbahaya secara politis. Apalagi dalam gerakan Sanusiyah banyak menekankan arti pentingnya ijtihad dalam ajarannya, dan itu dianggap kekufuran oleh ulama al Azhar yang beraliran Maliki.

Terusirnya Sanusi dari Makkah, semakin menambah semangatnya untuk mengembangkan sayapnya hingga gerakannya sampai di Cyrenaica Libya. Dan 
disitulah ia membangun zawiyah $B a^{\prime}$ idah pada tahun 1843. Disitu pula pengikutnya semakin banyak dan pada tahun-tahun berikutnya ia memilih Jaghbub sebgai pusat kegitannya sampai pada wafatnya tanggl 7 September 1859 M ( 9 shafar $1276 \mathrm{H}$ ) dengan meninggalkan dua orang putra yaitu Muhammad Al mahdi al Sanusi (1844-1902) dan Muhammad Al Syarif Al Sanusi (1846-1896) yang kelak menggantikan posisi ayahnya untuk menjadi pemimpin gerakan Sanusiyah.

Di bawah kepemimpinan al Mahdi gerakan ini mencapai puncak kejayaannya. Gerakannya terbentang luas di Afrika Utara, Afrika Barat, Danau Chad begitu juga sampai di laut Tengah. Dari beberapa pendapat pengamat mengatakan bahwa penyebab keberhasilan al Mahdi akibat adanya opini yang berkembang ketika itu bahwa dia sesuai dengan namanya dianggap sebagai Imam mahdi yang ditunggu-tunggu, yaitu Imam Mahdi yang dibimbing Tuhan untuk membawa Islam kearah kebenaran. Akan tetapi ia menolak julukan itu, lalu ia menjelaskan bahwa dakwahnya adalah untuk memperbaharui Islam dengan damai bukan melalui pertumpahan darah. ${ }^{3}$

Pada Masa al Sanusi, gerakan Sanusiyah pure berorientasi pada dinamisasi ajaran-ajaran sosial-keagamaan. Namun pada saat al Mahdi naik dalam tampuk kekuasaan, orientasi itu bergeser kepada ekonomi, sosial dan politik. Oleh karena itu pada tahun 1895 ia memindahkan pusat kegiatannya ke Kufra dengan beberapa pertimbangan : untuk menjahui pengaruh Turki Utsmani, kesadaran al Mahdi akan kepentingan Itali di Libya, pendudukan Inggris di Mesir membuat Jaghbub mudah untuk diserang, 'sementara itu Kufra sangatlah representatif untuk benteng pertahanan. Namun empat tahun kemudian al Mahdi memindahkan lagi pusat kegiatannya ke Qiru di Sudan Tengah, karena ia melihat Prancis sebagai ancaman bahkan pada tahun 1902, gerakan Saniusiyah diserangnya. Dan pada tanggal 30 Mei tahun itu juga beliau wafat. Kemudian pucuk pimpinan diserahkan kepada keponakannya yaitu Ahmad al Syarif. Evans-Pritchard membagi masa kekuasaan al Syarif menjadi tiga periode yaitu pertama, mulai tahun 1902-1912 dimana Syarif dengan tegas menentang dan melawan Perancis di Sahara. Kedua, mulai tahun 1912-1918 adalah periode Syarif melawan Italia dan Inggris di Cyrenaica. Dan yang ketiga, mulai tahun 1918-1933 adalah periode Syarif mulai mundur dari dunia politik. ${ }^{4}$ Dengan demikian tampak jelas bahwa pada periode pertama dan kedua ia langsung terjun dalam dunia politik praktis dalam melanjutkan kelangsungan gerakan al Sanusiyah dan itu akibat kondisi yang mengharuskannya

Ulul Albab, Vol. 5 No. 2, 2004 
untuk terlibat langsung pada konstalasi politik saat itu. Dan sejak ia mundur dari panggung politik gerakan Sanusiyah dilanjutkan oleh Ahmad Idris dibantu Sidi Umar Muhktar dalam perjuangan melawan Italia dan Inggris, hingga ia dinobatkan menjadi Raja Idris I di Libya.

\section{Organisasi Gerakan Sanusiyah}

Zawiyah yang telah didirikan gerakan Sanusiyah menjadikan pusat kegiatannya disana semakin padat. Dan istilah Zawiyah ini juga banyak digunakan gerakan-gerakan sufi lainnya. Sebab zawiyah yang secara etimologinya berarti pojok, corner atau tempat tersendiri. Dan dalam tradisi sufisme zawiyah sebagai tempat berkumpul para anggota gerakan sufi untuk melakukan latihan dan praktek kesufian. Bahkan ia juga digunakan untuk tempat pendidikan dan latihan (literatur yng berbahasa inggris menyebutnya lodge: pondok)

Adapun disain zawiyah terdiri atas dua bagian, satu untuk tempat tinggal sang Guru dan keluarganya, satu lagi dipecah menjadi tiga tempat bagian yaitu masjid, sekolah (ruang belajar) dan ruang tamu. ${ }^{6}$. Zawiyah ini juga digunakan sebagai pusat perlindungan para kafilah yang berdagang antara pesisir laut Tengah dan Sudan Tengah. Karena saat itu lalu-lintas perdagangan begitu ramai sehingga beberapa pejabat Sanusiyah mengusulkan perlunya ditingkatkan akomodasi itu semua keperluan itu. Wal hasil usaha tersebut mendatangkan devisa yang tidak sedikit bagi gerakan Sanusiyah seperti hasil dari transaksi penjualan dan pajak bagi suku yang tidak tinggal dalam lingkungan (bukan anggota) zawiyah.?

Sedangkan sistem organisasi tiap-tiap zawiyah dipimpin oleh seorang administrator yang biasanya disebut muqoddim yang diangkat oleh kepala zawiyah, setelah mendapat persetujuan dari suku dimana dimana zawiyah itu berada.

Zawiyah yabg berada di Jaghbub mobilitasnya semakin meningkat, sehingga disana menjad pusat belajar, karena didalamnya terdapat perpustakaan yang mengoleksi tidak kurang dari 8000 literatur. Disamping melakukan pendidikan terhadap para pelajar tak luput pula kaderisasi dilakukan disana. Dan materimaterinya berkisar pada ajaran-ajran keagamaan, bidang-bidang sosial-ekonomi dan politik. 


\section{Doktrin Sufisme Gerakan Sanusiyah}

Ajaran-ajaran yang diberikan dalam gerakan ini merupakan produk sintesis intelektual dari interaksi antara al Sanusi dengan situasi lingkungan dan zamannya. Dan inti utama produk sintesis itu adalah bahwa al Sanusi - dengan mengikuti gurunya Ahmad Ibn Idris - ingin mengembalikan ide-ide dan ajaran sufisme kedalam pangkuan syari'ah dengan menitikberatkan tekanannya pada persoalanpersoalan sosial dan moral.

Sanusi dalam sepanjang hidupnya telah banyak menguraikan inti ajarannya ke dalam berbagai paradigma, seperti teologi, fiqh, hadits, sejarah dan sastra. Dan semuanya itu telah terdokumentasikan dengan baik sebagai karyanya yang sangat berharga. Diantara karya utamanya yaitu al Salsabil al Ma'in fi al Thara'iq al Arba'in, Bugyah al Maqoshid fi Khulashoh al Marasid dan Iqadz al Wasnan fi al A'mal bi al Hadits wa al Qur'an.

Dalam bukunya al Salsabil ia mendeskripsikan pengalamannya dalam dunia sufisme. Ia menekankan bahwa sufisme merupakan salah satu jalan menuju keselamatan (Tuhan), selain syari'ah. Akan tetapi ia juga menyangkal adanya ajaran-ajaran sufi yang salah akibat sempitnya pengetahuan tentang sufisme itu sendiri. Ia juga mengupas tentang pengaruh sufisme terhadap dirinya. Salah satu pengaruh yang paling terkesan baginya adalah datangnya dari ghozali. Sebagaimana diketahui Al Ghozali merupakan orang yang paling berhasil mengintegrasikan kontradiksi antara sufisme dengan syari'ah. Dan memang Imam Ghozalilah seorang ulama besar yang telah sanggup menyusun kompromi antara syari'at dan hakekat atau tasawuf menjadi bangunan baru yang cukup memuaskan bagi keduanya. ${ }^{8}$ Selain itu pula ia menyebut banyak dipengaruhi oleh pemikiran Ibnu Taimiyah.

Menurutnya gerakan sufi yang ideal haruslah menggunakan ungkapanungkapan yang sederhana dalam penyampaian peringatan serta menggunakan ayat-ayat al Qur'an sebagai sandaran. Dan dalam prakteknya gerakan ideal itu juga menggalakkan seruan team work (kooperatif), persaudaraan dan solidaritas.

Dengan demikian gerakan tersebut akhirnya terwujud dalam bentuk gerakan sanusiyah itu sendiri, dengan beberpa tekanan doktrinal dan praktik sufisme yang agak berbeda dengan gerakan-gerakan lain. Dan perbedaaannya yang paling menonjol adalah al Sanusi cenderung menghindarkan ajaran-ajaran sufismenya dari pembicaraan tentang keberadaan "orang suci" (karamah al Auliya) kejadian 
atau peristiwa "luar biasa" dan yang semacamnya. Jadi kultus individu dan kepercayaan tahayul tidak terdapat dalam ajaran al Sanusi. Karena ajaran utamanya adalah latihan praktis untuk mensucikan jiwa dan rasa cinta sesama anggota.

Al Sanusi juga banyak mengkritik para ahl Hadits yang menurutnya banyak melakukan kesalahan dalam menginterpretasikan dan mengaplikasikan Hadits. Ebab menurutnya dalam memperlakukan hadits pemahaman tentang konteks ruang dan waktu dimana hadits itu didapat. Sedangkan untuk sampai pada pemahaman al Quran dan sunnah al Sanusi sangat menekankan pada arti pentingnya ijtihad. Namun seperti Ibnu Taimiyah ijtihad yang dimaksudkan adalah ijtihad terhadap teks-teks al Qur'an dan Hadits yang ada dan tersedia, baik eksplisit maupun implisit. Jika tidak ada teks maka ijtihad dilarang.

Pandangan Sanusi itu tentunya bertentangan dengan apa yang diakui saat itu pintu ijtihad tertutup dan kaum muslim hanya bertaqlid kepada satu dari empat mazhab, akan tetapi ia tidak menerimanya dan mengatakan : "tidak ada keharusan mengikuti satu dari imam yang empat. Sebab tidak ada kewajiban selain apa yang diperintahkan Allah dan RasuNya. Allah dan Rasul tidak mewajjibkan siapapun untuk bermazhab kepada satu mazhab dan mengikutinya secara mutlak. Bahkan tidak sah seseorang menentukan suatu mazhab untuk diikutinya. Andaipun telah dia tentukan, tidak mesti dipatuhi."

Dengan demikian jelaslah bahwa dalam pandangan Al sanusi pintu ijihad tetap terbuka, terutama bagi orang-orang yang benar-benar mengetahui dan mamahami al Qur'an dan Sunnah secara mendalam.

\section{Potret Politik Gerakan Sanusiyah}

Doktrin-doktrin dan ajaran -ajaran tentang politik yang kumandangkan oleh al Sanusi memang baru tampak pada masa-mas akhir. Ia kata Muahmmad As'ad memang tidak pernah bermaksud untuk mendirikan pemerintahan bagi dirinya sendiri atau pengikutnya, namun targetnya adalah persiapan suatu basis organisasi dan politik demi kebangkitan Islam. ${ }^{9}$ Satu-satunya kunci utama doktrin politik gerakan Sanusiyah adalah konsep jihad. Maksud konsep jihad disini adalah perang suci melawan kolonialisme yang menjajah kemerdekaan kaum muslim. 
Dan jika tidak mampu mempertahankan kekuatan, mereka lebih baik pindah tempat (hijrah ; migrate) ${ }^{\prime o}$ Inilah yang banyak pengamat menyebabkan bahwa saat itu gerakan Sanusiah benar-benar dianggap musuh orang eropa."

Sementara itu kekuatan Islam lainnya Turki Ustmani sangat mendukung melihat perkembangan gerakan sanusiyah yang begitu maju. Dan menjadikan hubungan keduanya semakin baik. Selain itu,meski pengaruh sosial politik gerakan Sanusiyah dapat diakatakan lebih besar dari Turki Utsmani, para pemimpinnya tetap menghormati Turki Utsmani dan tetap menganggapnya sebagai penguasa muslim.

Bahkan bila kita lihat dalam konteks dinamika orientasi politik gerakan Sanusiyah, gambaran tentang hubungan Turki Utsmani dengan gerakan Sanusiyah sangatlah menarik. Dan yang paling jelas adalah meski secara politis kekuasaan gerakan sanusiyah berada diatas kekuasaan pemerintahan Turki Utsmani, namun mereka tetap menghormati dan menganggapnya sebagai Khalifah. Dari sini dapatlah kita perkirakan bahwa mungkin inilah faktor yang menyebabkan mengapa al Sanusi lebih menekankan orientasinya kepada persoalan keagamaan dan pasif dalam politik praktis.

\section{Endnotes}

1 Lihat, Fazlur Rahman, Islam, Second Edition (Chicago : The University of Chicago Press, 1979) Hal.205-6

2 Azyumardi Azra, Akar-akar Historis Pemaharuan Islam di Indonesia : Neo-Sufisme Abad ke 11-12 H/17-18 M

3 Edward Mortimer, Islam dan kekuasaan, (Bandung, Mizan, 1984) Hal. 65

4 Nicola Ziadeh, Sanusiyah: A Study of A Revivalist Movement in Islam (Leiden: EJ. Brill, 1983) Hal.59-60

5 Asep Usman Ismail, Gerakan Sanusiyah di Afrika Utara : Profil Gerakan Tarekat yang berwawasan Sosial, Pelita, Jakarta, 23 Pebruari 1992

6 C.C.Adams, The Sanusis, The Muslim World, 1946,Hal. $31-31$

7 Ibid... Gambaran tentang lalu lintas perdagangan, peranan gerkan Sanusiyah dalam bidang ini dapat dilihat dalam Denis D. Cordell, Estern Lybia, Wada;I and The Sanusiya: A Tariqa and Trade Route, Journal of African History, XVIII, I (1977) Hal.21-36 
${ }^{8}$ DR. Simuh, Tasawuf Dan Perkembangannya Dalam Islam, PT. Rajagrafindo Persada, Jakarta, 1997, Hal. 159

${ }^{9}$ Muhammad As'ad, The Sanusis and The Struggle Againts Italian Colonialism in Lybia, an Nahdah, Vol.2., No.4, Oktober -Desember 1982, Hal. 6

${ }^{10}$ Nicola Ziadeh, Op Cit. Hal. 90-91. Tinjauan kritis tentang konsep jihad ini, lihat Rudolph Peters, Islam and Colonialism: The Doctrine of Jihad in Modern History, (New York. Mouton Publishers, 1979), 85-87

"Nicola Ziadeh, Ibid

\section{Bibliografi}

DR. Simuh, Tasawuf Dan Perkembangannya Dalam Islam, PT. Rajagrafindo Persada, Jakarta, 1997

Azyumardi Azra, Akar-akar Historis Pemaharuan Islam di Indonesia : NeoSufisme Abad ke 11-12 H/17-18 M

Asep Usman Ismail, Gerakan Sanusiyah di Afrika Utara : Profil Gerakan Tarekat yang berwawasan Sosial, Pelita, Jakarta, 23 Pebruari 1992

Fazlur Rahman, Islam, Second Edition (Chicago: The University of Chicago Press, 1979)

Edward Mortimer, Islam dan kekuasaan, (Bandung, Mizan, 1984)

Nicola Ziadeh, Sanusiyah: A Study of A Revivalist Movement in Islam (Leiden: EJ. Brill, 1983)

C.C. Adams, The Sanusis, The Muslim World, 1946

Denis D. Cordell, Estern Lybia, Wada; I and The Sanusiya : A Tariqa and Trade Route, Journal of African History, XVIII, I (1977)

Muhammad As'ad, The Sanusis and The Struggle Againts Italian Colonialism in Lybia, an Nahdah, Vol.2., No.4, Oktober-Desember 1982

Rudolph Peters, Islam and Colonialism: The Doctrine of Jihad in Modern History, (New York. Mouton Publishers, 1979)

Nasrullah Alief, Gerakan Neo Sufisme Sanusiyah di Afrika Utara (Ulumul Qu'an No. 2/VII/1996) 